\title{
Transnational Authority in the Knowledge- Based Economy: Who Sets the Standards of ICT Training and Certification?*
}

\author{
JeAn-Christophe Graz \\ University of Lausanne
}

AND

Eva HaRTMANN

University of Kassel

\begin{abstract}
This article examines the extent and limits of nonstate forms of authority in international relations. It analyzes how the information and communication technology (ICT) infrastructure for the tradability of services in a global knowledge-based economy relies on informal regulatory practices for the adjustment of ICT-related skills. By focusing on the challenge that highly volatile and short-lived cycles of demands for this type of knowledge pose for ensuring the right qualification of the labor force, the article explores how companies and associations provide training and certification programs as part of a growing market for educational services setting their own standards. The existing literature on non-conventional forms of authority in the global political economy has emphasized that the consent of actors, subject to informal rules and some form of state support, remains crucial for the effectiveness of those new forms of power. However, analyses based on a limited sample of actors tend toward a narrow understanding of the issues concerned and fail to fully explore the differentiated space in which nonstate authority is emerging. This article develops a three-dimensional analytical framework that brings together the scope of the issues involved, the range of nonstate actors concerned, and the spatial scope of their authority. The empirical findings highlight the limits of these new forms of nonstate authority and shed light on the role of the state and international governmental organizations in this new context.
\end{abstract}

"Global knowledge-based economy" has become a popular term for ongoing changes in contemporary capitalism. The service sector is at the core of changes that require a constantly evolving stream of specialized skills. The crucial role of knowledge in a postindustrial society, where the delivery of services supersedes the production of goods, was identified over 30 years ago by Daniel Bell (1973). Similarly, Manuel Castells has analyzed the rise of the network society around

*The authors would like to thank the three anonymous reviewers for their helpful comments on a previous version of the contribution, Liesl Graz for her help with the language, and the Swiss National Science Foundation (SNF) for its support (grant PP001-110528 Standards and International Relations: Devolution of Power in the Global Political Economy). 
communication and information infrastructures and services as a distinct form of knowledge creation in information processing and diffusion (Castells 2001:56). The information and communication technology (ICT) infrastructure has dramatically increased the tradability of services, promoting further economic integration. Numerous studies have examined the impact of the new ICT infrastructure on global governance and highlighted the role of the private sector and civil society in undermining the principle of territoriality in this domain (Comor 1999; Weiss 2005; Anzelmo 2006; Sassen 2006). While the importance of private regulations in the context of the Internet Corporation for Assigned Names and Numbers (ICANN) for electronic commerce and trade in services has been intensively analyzed (Wilson 2005; Drissel 2006; Mathiason 2009), little systematic research has been carried out on the governance structure of ICT training and certification programs, with its own mode of standard setting. ${ }^{1}$ The lack of research is particularly surprising given the challenge this type of training poses for existing governance structures in the sphere of training and the labor market. ICT training and certification has a direct impact on labor processes and access to labor markets as they set predefined competences supposedly required for ICT user and supply companies, as well as ICT practitioners in public and private sectors. Almost all jobs in the service sector in industrialized and emerging countries require some kind of ICT skills. Ultimately, ICT training and certification challenges traditional state and corporatist regulations inherited from a time when education and training existed only in physical classrooms, or was part of vocational or very context-specific on-the-job training. Beyond the specificities related to ICT, a closer analysis of this topic also provides insights into more general challenges which confront the qualification strategies of the labor force where knowledge requirements are fast changing, where education and training have been partially commodified as part of the service economy, and where the labor market has become international.

How can the power of companies and associations to provide such highly privatized and internationalized ICT training and certification programs be appraised as part of a growing global market for educational services setting their own standards? Most analyses of nonstate and private authority in international affairs focus on a limited sample of actors among large multinational corporations and non-governmental organizations. Even when they are more inclusive, they offer little differentiation between agents competing for legitimacy as representatives of civil society. As to the object on which such authority can be exercised, studies also tend to have a narrow understanding of the issues involved. Recent research has led to some fruitful studies on the rise of private authority in domains such as finance, labor, the environment, consumer issues, and security (Hallström 2004; Levy and Newell 2005; Anzelmo 2006; Prakash and Potoski 2006; Duffield 2007; Mattli and Woods 2009; Mügge 2010; Ougaard and Leander 2010; Mattli and Buthe 2011). Yet similar phenomena are arguably as fundamental in other fields of the emerging global knowledge-based economy. Finally, when it comes to the spread of authority, despite the growing number of studies debating the advent of a post-Westphalian world order, few fully explore

\footnotetext{
${ }^{1}$ Research on ICT training and certification is dominated by market studies (for example, Certification Magazine or Computer World), employers' organizations' analyses (CompTIA 2004; CEPIS 2007), and information provided by public entities (cf. Adelman 2000; Australian Governement 2011). At the regional and international level, a number of studies on the demand of ICT-related skills have been carried out by the European Centre of the Development of Vocational Training (CEDEFOP 2009), the Organisation of Economic Cooperation and Development (OECD 2010), the World Bank (World Bank 2011), and the United Nations Development Programme (UNDP 2007). Unsurprisingly, market studies are descriptive whereas studies commissioned by public entities tend to be more policy-oriented; neither provides a conceptual understanding of the transformation of the governance structure of qualification and skill provisions in the context of the arising market of ICT-related training and certification.
} 
the differentiated space in which nonstate actors and less conventional forms of domination seek recognition in the reconfiguration of states' distinctive form of spatial production. ${ }^{2}$

Against this background, the objective of this article is to engage current scholarship on the reshaping of authority in international relations. It does so by examining the role and limits of ICT training and certification in the rise of a global knowledge-based economy through the lens of a three-dimensional framework: the scope of the issues involved; the range of nonstate actors concerned; and the reconfiguration of the scale and spatial scope of their authority. In the distinctive domain of ICT educational and training services, the case study highlights that standards and certifications are likely to follow two competing routes: on the one hand, more commodification of technical market-based certifications of industry products claiming a global reach, and on the other hand, a re-embedding process of ICT certifications of skills implying societal concerns taken over by professional associations together with official standard-setting bodies. The paper argues that the more technical specifications take social behavior into consideration, the more profit-oriented nonstate actors face limits to their authority on a transnational basis. Such intrinsic limits of nonstate and private authority in international relations have wide implications and shed light on the role of a distinct institutional framework to ensure some order at the transnational level. As such, they also reflect the potential impact of contested power relations in civil society at both the domestic and international levels.

The material used for the empirical foundation of the study is based on comprehensive literature reviews, printed and Internet-published material of the specialized press and key actors related to the field of post-secondary education, standardization, and ICT training and certification.

The first section provides some background on ICT training and certification programs, including the supposed need for continuous adjustment of skills in a knowledge-based economy. The next section proposes an analytical framework for examining nonstate and private forms of authority in international relations. It presents the conceptual framework bringing together the three dimensions of the scope of issues concerned, the range of actors involved, and the scale and spatial scope on which such authority is projected. The third section examines the different types of international standards for ICT training and certification in detail and considers tensions across the configuration of power, giving a larger role to private actors. We thus analyze what gets certified, who has the authority to certify, and where and whence ICT training and certification becomes authoritative. It is within the context of those tensions that the article finally identifies competing scenarios for the future development of certification used in a timely, reliable, and constant renewal of ICT skills. The conclusion recapitulates the argument and draws implications for the understanding of nonstate forms of authority in international relations.

\section{Education and Training in a Knowledge-based Economy}

Increasing competition in the knowledge-based economy leads to an ever shorter life cycle of knowledge. The ICT sector is perhaps the most significant domain in which rapid change not only changes the industry, but also impacts upon its enabling environment (Zuurmond 2005). Constant adjustments in skills are crucial for the full potential of ICT to be realized.

Lifelong learning is the buzzword of the new education strategy in the knowledge-based economy. Lifelong learning challenges the education system by

${ }^{2}$ Notable exceptions include Cameron and Palan 2003; Palan 2003:162-80; Brenner 2004; Sassen 2006:378-90. 
reorganizing the relationship between formal, informal, and nonformal education. ${ }^{3}$ Formal education refers to the highly institutionalized, chronologically graded, and hierarchically structured education system beginning in primary school and ending at the tertiary level. Nonformal education concerns activities organized and carried on outside the framework of the formal system, for example, training courses offered by a company or an association. Informal learning includes the acquisition and accumulation of knowledge, skills, and insights from daily experience and exposure to the environment. Although unorganized and often unsystematic, it accounts for the great bulk of any person's total lifetime learning. As the lifelong learning strategy aims at expanding nonformal education and valorizing informal learning, it profoundly alters the interplay between formal, nonformal, and informal education.

Many proponents see market-driven offerings as the best way of ensuring the timely, flexible, and tailored provision of new skills in an economy with a drastically shortened life cycle of knowledge. A case in point is e-learning, which has become a privileged vehicle for promoting nonformal training and education. ${ }^{4}$ The trend toward market-driven provision is ever more pronounced in the field of ICT training and certification (CEDEFOP 2006). A certification should not be confused with a certificate that merely documents that an individual has successfully completed a course or a class. The European institute CEDEFOP defines it as the "process of issuing a certificate, diploma or title formally attesting that a set of learning outcomes (knowledge, know-how, skills and/or competences) acquired by an individual have been assessed and validated by a competent body against a predefined standard" (CEDEFOP 2008:41). Microsoft, for instance, confers the title Microsoft Certified Solution Developer (MCSD), which states that the certified person's skills meet the Microsoft standards with regard to planning, deploying, supporting, maintaining, and optimizing IT infrastructures. ${ }^{5}$ Such certifications are often portrayed as being better suited to address qualification needs than traditional, more generic post-secondary education. As employers continually try to adjust and augment the skills of their workforce, such highly specialized, market-driven ICT training and certification presents an appealing option for them. It may also be attractive to ICT workers in their constant effort to maintain and increase their "value" in the labor market. Many experts praise industry-based certification (IBC) as a model not only for ensuring quality standards in the provision of nonformal education, but also for valorizing informal learning since work experience is an entry requirement for many ICT training courses (Summerfield 2007). In this sense, certifications closely linked to predefined standards fulfill a micro-governing function by defining what knowledge and competence ICT workers need to have. As a consequence, they have an influence on the definition of job profiles and thus on the qualification structure of the labor market.

This has direct implications for any form of governance in this field and strengthens the position of private providers of nonformal education and certification. The standard-setting authority in this domain has become so prominent that Adelman calls ICT certifications a "parallel universe" to state-recognized higher education institutions, which conventionally enjoyed the monopoly in conferring educational titles (Adelman 2000). Adelman's analysis tends to overlook the corporatist tradition, notably in countries with a well-established vocational system, where companies set educational standards in collaboration with government agencies and trade unions. It does, however, spotlight an important

\footnotetext{
${ }^{3}$ This distinction draws on the work of Coombs 1968 and Coombs and Ahmed 1974.

${ }^{4}$ See Povalej and Weiß 2007:41; IDC 2008. There is currently a remarkable growth in China (Tong 2008).

${ }^{5}$ See www.microsoft.com/learning/en/us/certification/exam.aspx (accessed March 2, 2012).
} 
change in private sector involvement in the definition and provision of training as it becomes more profit-oriented and less embedded in a corporatist structure.

This market-driven orientation facilitates the internationalization of the new governance structures. As in e-learning, a worldwide market in certification is emerging, led by the United States, followed by Europe and increasingly by other regions of the world. Its volume nearly quadrupled between 2000 and 2007 (CEN 2009:11). A 2007 study conducted by the online journal Certification Magazine, with more than 35,066 IT professionals from 195 different countries participating, shows that approximately $94 \%$ of the respondents were certified, with an average number of 3.31 certifications. ${ }^{6}$ These figures indicate that ICT certification is a significant player, despite its neglect in conventional studies of post-secondary education. This success has also turned ICT certifications into a role model for other qualification areas, where certification through private providers is gaining in importance. ${ }^{7}$ In spite of the economic crisis that also hit this sector, the market has remained relatively firm with the prospect of slow recovery by 2013 with US $\$ 26$ billion in revenue and the Asia/Pacific area at the forefront (O'Sullivan, Weiß and Sharkov 2011:17-18; CompTIA 2012). The emerging market in ICT training and certification raises the issue of the authority of voluntary standards in the emerging global knowledge-based economy. This makes an appealing case for reassessing the question of nonstate and private authority in international relations.

\section{Nonstate Actors and the Ascendancy of Standards}

Nonstate actors lead to new forms of power and authority in international relations. The literature on the rise of nonstate actors, private authority, and less conventional forms of sovereignty and governance has mushroomed over the last decade. ${ }^{8}$ A shared assumption of this scholarship, whatever its theoretical positions, is that at least two conditions must be met for such new forms of authority to be effective: first, the consent of actors who are subject to the rules without having been involved in their making and, second, explicit or implicit support from the state.

Consent-rather than coercion or enforced compliance-is an important element in such configurations of power. According to Cutler et al. (1999:19), "those subject to the rules and decisions being made by private sector actors must accept them as legitimate, as the representations of experts and those in authority." In the same vein, Djelic and Sahlin-Andersson (2006:23) consider that nonstate authority enabling various forms of transnational governance hinges upon "powerful institutional forces that altogether constitute a transnational culture or meaning system." The authority of nonstate actors in international relations is a form of normative power closely related to reputation, which substitutes command-and-control hierarchical and formal state regulation for informal and nonhierarchical governance. Nonhierarchical "steering modes," based on private-public partnerships, are therefore a central feature in the debate on the legitimacy of this new type of normative power (Risse 2006). As

\footnotetext{
${ }^{6}$ Even if these figures are biased toward the United States, where $37 \%$ of the respondents lived at the time of the study, they nevertheless indicate a global spread of certifications. $11.6 \%$ of the respondents lived in India at the time of the study, 4.4\% in the United Kingdom, and 4\% in Canada (Margolis 2007:21).

${ }^{7}$ Another important field of global certification has emerged with regard to language testing. The best-known provider in this field is the nonprofit organization Educational Testing Service (ETS) with its English language test TOEFL or the British Council's International English Language Testing System (IELTS) (Fox, Wesche, Bayliss, Cheng, Turner and Doe 2007).

${ }^{8}$ See among others: Graz and Nölke 2008; Krause Hansen and Salskov-Iversen 2008; Grande and Pauly 2005; Cutler, Haufler and Porter 1999; Hall and Biersteker 2002; Higgott, Underhill and Bieler 1999; Sassen 2006; Strange 1996; Djelic and Sahlin-Andersson 2006; Avant, Finnemore and Sell 2010.
} 
Egan (2001:161) points out with regard to the distinct area of technical standardization, this "usually involves much cognitive uncertainty concerning appropriate solutions, given differences in risk assessment, scientific uncertainty, and goals of regulation, so that building a consensus also depends upon reputation, expertise, and credibility." Graz and Nölke (2008:14) remind us, however, not to overemphasize the consensual underpinning of nonstate authority, which more accurately invents "new channels in the relations between formal and informal procedures, as well as hierarchical and nonhierarchical mechanisms of social action."

Although explanations may differ according to competing theoretical approaches, states remain central in the rise of private actors in both domestic and international affairs. For example, scholars with a background in neocorporatist studies are likely to emphasize the "shadow of hierarchy" required for effective self-regulation (Héritier 2002; Smismans 2004). Meanwhile transnational historical materialists tend to see private actors and the state as two different expressions of a larger configuration of social forces (Gill 1993; Holman 2008). While there may be sharp disagreements on the significance attributed to state recognition, there is little disagreement concerning the overall complementary and subsidiary role of private actors with regard to state functions. As Sassen (2006:170-171) argues, "the redistribution of power within the state is a consequence of changes in both the national and the international political economy but is also constitutive of those changes." Governments and intergovernmental institutions often support and fully recognize the power of nonstate actors, who in turn may enhance their legitimacy. The territorial basis of the state and the structural power of governments and markets remain beyond various forms of nonstate authority. This explains the limits within which this phenomenon is transnationalized, whether purely private or based on informal and consensual forms of collective action (Graz and Nölke 2008).

The literature provides useful conceptual tools to clarify how a new range of actors have gained authority in an international context that traditionally denied them such a privilege. It includes in-depth analyses of firms and interfirm cooperation leading to political roles for those traditionally associated with the private sphere of economic transactions. While analyzing interfirm and cross-border cooperation, the literature primarily focuses on the actors involved in the process. Two aspects which play a key role in the rise of new sources of authority in the current reconfiguration of global capitalism are subsequently left behind: the scope of issues involved and the reconfiguration of the spatial structure in which such practices are implemented. Any analysis of the effectiveness of such authority requires a more detailed understanding than shared assumptions about the consent of actors and the support of the state. The remainder of this section addresses this issue by examining how technical specifications and standards upon which ICT training and certification relies reflect a distinct form of nonstate authority in international affairs.

Three closely related dimensions merit further investigation in understanding how nonstate actors become standard setters for power configurations in the contemporary global political economy: (i) the scope of issues concerned; (ii) the range of nonstate actors involved; (iii) the reconfiguration of the scale and spatial scope of their authority.

(i) Scholarship on the rise of nonstate authority tends to have a narrow understanding of the scope of issues involved. Most studies consider a limited number of cases rather than the many domains affected by the phenomenon. A growing mountain of material has been published on risks associated with selfregulation in global banking and finance; the private governance system of cyberspace and the Internet; the rise of private military companies; the wide use 
of codes of conduct; benchmarking and voluntary schemes in labor; and ecological and consumers' concerns. Less fashionable subjects include insurance, business services, intelligent transport, and also professional training. ${ }^{9}$ Small wonder, then, that most studies fail to conceptualize the full range of nonstate authority. As Hewson and Sinclair (1999:10) suggest, new directions for global governance spring "in large part from the global changes associated with the technologies of the emerging worldwide knowledge order." From this perspective, new forms of nonstate authority are based on technical expertise and professional eminence. Studies in science, technology, and society have long emphasized how, far from being restrained to narrow techno-scientific solutions, the process through which such rules are constructed requires comprehensive practices of rationalization, calculation, and objectification of social and economic relations (Callon 1998). These practices of measurement provide useful tools to influence society and therefore reduce potential spaces of political contestation (Higgins and Larner 2010). As Loconto and Busch (2010:509) point out, “'calculativeness' depends not only on the weights and measures of metrology (as referred to by Callon), but also on reference materials, written specifications, conventions, codes of ethics, laws, and regulations - in other words, standards." The set of issues concerned thus tend to closely link the societal stakes of collective life with its material, natural, and, more generally, physical dimension. The spectrum ranges from crystal-clear physical questions to the highly contentious social requirements of a material civilization.

Drawing on this understanding, the question for our analysis of ICT training and certification is: What gets standardized and certified? In other words, to what extent do technical specifications include social values, and how does this impact upon the shape and strength of nonstate authority? By affecting distinct classes of objects, technical specifications reflect what can be standardized. Technical specifications and certification programs are likely to involve broader societal concerns given the intangible and relational nature of this type of economic transaction. We therefore suggest a broader understanding of standardization that includes, in a narrow sense, the definition of voluntary specifications on distinct issue areas with defined documents, and, in a wider sense, the self-reproducing domination through which an ensemble of beliefs and norms becomes so internalized that it appears natural and inevitable. This broader scope of standardization encompasses a more structural understanding of power, framing the way individuals and groups understand themselves, and the possibility of changing their situation. In sum, such a perspective brings to the fore the broad social concerns and new configurations of nonstate power, which are underpinned by the regulatory policies related to technological change and innovation.

(ii) Particular attention must thus be paid to the mix of private and public actors in nonstate forms of authority and the reasons why their demands can become effective. As Feenberg (1991:14) reminds us, rather than seeing technology as a neutral tool, it should be viewed as a "parliament of things on which civilizational alternatives are debated and decided." This perspective emphasizes the significance of having a proper understanding of the great variety of actors who have the authority to determine and certify technical specifications. The range of private actors to be considered depends on the definition of the private/public distinction and its interplay with the sphere of civil society. Despite variations between societies, the separation between the modern state and the economy has shaped social relations by distinguishing between the private and the public sphere (Cutler 2003:141-179). They remain closely

\footnotetext{
${ }^{9}$ On professional qualifications, see Hartmann 2008; on insurance, see Haufler 1997; Ericson, Doyle and Barry 2003; on business services, see Miles and Miozzo 2002; Graz and Niang 2012 forthcoming; on intelligent transport systems, see Sussman 2005.
} 
related, reflecting two sides of the same coin. While the public sphere confers universal rights in the political domain, the private sphere brings into play such rights in order to provide limited contractual rights in the economic and civil domains. The range of private actors claiming authority in international affairs is thus larger than what we refer to as the "private sector" in narrow economic terms. It may include nonstate actors, such as trade unions, activist groups, women's organizations, professional associations, cadres and experts organized in ad hoc bodies, advocacy or policy networks, elite clubs, and religious groups. This implies that the "private" authority of nonstate actors in international relations potentially includes any collective actor organized through formal or informal contractual relations within the ambit of civil society. As Colàs (2002:23) argues, civil society should not be viewed as a benign sphere of collective action outside the state system, but rather as a "space of contested power relations where clashing interests play themselves out through analogous but unequal modes of collective agency." The contests may assign authority to some actors while undermining the authority of others.

Against this backdrop, our analysis attempts to identify the crucial actors involved in the standardization process in the sphere of ICT training and certification. It asks which actors within civil society, and what interactions with the system of states, are most prominent in constituting the authority of technical specifications and certification, and so enabling the rise of a global knowledgebased economy. Market mechanisms and policy choices both affect the agents involved, but they do so in different ways. Technical specifications belong to the private sphere of economic activities governed by market constraints and affect social and technological changes from that angle. Some scholars remind us that even in this private sphere, public policy continues to play an important role, notably with regard to establishing principles of liability. In such cases, technical specifications involve standard-setting bodies with private or public statutes that can vary greatly (Hauert and Graz 2010). From this perspective, our empirical study explores the extent to which public entities are involved in the standardsetting processes of ICT-related training and certification.

(iii) A third, and often neglected aspect, is the wide spatial scope in which nonstate authority is exercised. While many studies stress that the logic of state sovereignty is being replaced by another reinforcing the transnational underpinning of capitalism, fewer highlight that what is significant is less the de-territorialization of state sovereignty as such than the reorganization of the logic at work in the production of space. Nonstate authority brings into play multiple scales with differentiated spatial scopes. It is premised on a new spatial ontology, closely related to the rise of the global knowledge-based economy (Amin 2004). Interdisciplinary scholarship, in what is usually referred to as the "scalar turn" in state analyses, has devoted extensive attention to what Jessop calls the "political economy of state rescaling" (Jessop 2002: Chap. 5; Brenner 2004, 2009). As Cerny (2009:150) points out, "the development of a range of transnational opportunity structures provides vital structural space for key agents to act in potentially transformative ways." Such practices are very malleable throughout history and rely upon a flexible transnational meaning system that tends to blur the exogenous and endogenous forces traditionally seen at work in the constitution of the territorial nation state. As Sassen (2006:223) emphasizes, in her studies of the "denationalization" of the US state and the privatization of norm making: "the rise of private authority is not simply an external force that constrains the state. It is partly endogenous to the state." By the same token, those rules partly depend on codifications provided by bodies exogenous to the state, such as the International Organization for Standardization (ISO), not-for-profit private entities such as the American Computing Technology Industry Association (CompTIA) in charge of a number of ICT certification programs, 
and private companies such as Cisco and Microsoft, providing tailor-made certifications for their own products. The projection of technical specifications beyond the territorial basis of state sovereignty reshapes social relations between and across states, even if major differences remain between sectors and countries. Accordingly, the spatial scope affected by such transnational processes is likely to follow the main lines of fracture and hierarchy of contemporary capitalism. Paraphrasing Brand (2005:171), we should be reminded of the extent of a "fragmented hegemony" that differentiates between what can be observed in the North and in the postcolonial world.

The question is then: Where and whence do standards and certifications become authoritative? More specifically, from this focus on the spatial dimension of nonstate authority, we will explore to what extent the implementation of standards and certification programs relies on conformity assessment procedures combining opposing principles of exogenous and endogenous recognition. Endogenous recognition applies the principle of "country of destination," whereby foreign providers must meet the domestic requirements of the importing country. This can involve multiple replications of tests and certifications on common standards before clearance is given for each market. In contrast, exogenous recognition endorses the "country of origin" principle, or international standards allowing suppliers to use a single test of conformity (whether selfdeclared or provided by a third-party certifier) for the global market. As Nicolaïdis and Egan (2001:455) observe, "domestic regulators accept unprecedented transfers of regulatory sovereignty by recognizing non-domestic standards as valid under their jurisdiction (...)." A global market characterized by the recognition of exogenous standards and certifications is however at considerable odds with conventional forms of territorial sovereignty.

In summary, and in contrast to conventional accounts focusing on the new actors involved in the regulation of the current transformation of global capitalism, the conceptual framework presented here also sheds light on the scope of the regulatory practices concerned and the reconfiguration of the spatial structure in which they are implemented. The rise of nonstate actors as standard setters for the global political economy thus entails the aggregation of three distinct categories: the objects - what is standardized and certified; the actors - who has the authority to set standards and certify them; and the space -where and whence standards and certifications become authoritative. It is through this three-dimensional analytical framework that the remainder of this paper studies the transnational authority of standard settings in ICT training and certification programs. It examines the extent to which the issues concerned relate to both technical and societal dimensions, the range of nonstate actors involved in the process, and the spatial scope of their authority. A brief section then examines present tendencies within ICT-related training and certification.

\section{The Authority of ICT Training and Certification Programs}

\section{What Gets Certified?}

Information and communication technology training and certification in a knowledge-based economy reinforces nonformal types of education in order to secure a timely and substantial supply of skills on a wide range of issues such as storage, system or network design, and implementation or risk and security management. It offers programs providing skills, quality standards for assessing skills, distinct standards for the corresponding assessment tools, and a wide range of mechanisms for tracking compliance, verification, and recertification. The complex includes criteria and safety measures for standardizing administration 
protocols in order to ensure that they are interoperable (CEDEFOP 2006:2527). Accordingly, certifications may be closely related to skill requirements in a narrowly defined technical field - the proper, effective, and efficient handling of ICT tools reflecting state-of-the-art software developments and the integration of computers in the overall production process. However, market observers underline the increasing importance of additional business skills, requiring a blend of subject matter expertise and business talent, together with narrower technology competences (Povalej and Weiß 2007:38; Lisican 2008; Foote Partners LLC 2011). As a result, a number of certifications have broadened the scope of their assessments by documenting personal attributes such as motivation or traits such as being organized, ethical, diplomatic, observant, or self-reliant. In other words, ICT training and certifications not only include technical specifications. They define broader values, whose societal dimension is not restricted to business talent, as conventional industry analysis would understand it. Accordingly, they are part of a transition away from the routine tasks prevailing during Fordism toward new forms of production. They ensure the full exploitation of the ICT infrastructure and also of the intelligence and creativity of ICT workers.

Information and communication technology training and certification also influences the recruitment process. By providing information on the knowledge required of individuals, they help employers to identify the right prospective employee. In other words, they reduce the information asymmetry of the labor market for employers. Since ICT training and certifications are often expensive, this information also indicates that workers are motivated to upgrade their skills and have the means to do so. ${ }^{10}$ Coincidentally, ICT training and certification may also empower ICT workers by making visible their work experience and expertise beyond formal qualification certificates. Most studies consider that those who do have relevant qualifications are generally more employable. A growing body of evidence shows that many employers take into account the certification of prospective employees and that this has an impact on their future earnings (Margolis 2007; Robert Half Technology 2011). In this regard, certifications also influence the relationship between capital and labor. Studies indicate that the highest impact seems to be at the lower end of academic qualifications, at bachelor's and master's degree levels, and less so with regard to IT professionals holding a PhD (Tegan et al 2006). In other words, at this upper qualification level, the formal qualification still defines the position in the wage hierarchies and the labor market, but this is less so at the lower end where nonformal qualifications have become another means of distinction and social recognition. The next section examines in more detail the major players of ICT certification.

\section{Who Certifies?}

Understanding the extent to which nonstate actors are able to exercise a widely recognized form of power in the domain of ICT training and certification prompts us to examine which actors within civil society, and what interactions with the system of states, are most prominent in constituting their authority in the emerging global knowledge-based economy. At present, a plethora of certifications has resulted in a fragmented and confusing landscape. The exact number of current certifications is difficult to determine. Analyses have found more than 100 providers operating more than 1300 individual certification products (O'Sullivan et al. 2011:6). The market is characterized by the presence of key and niche players. Some are related to specific platforms and products, while others focus more on skills, techniques, and knowledge (Tittel 2003). We can

\footnotetext{
${ }^{10} \mathrm{~A}$ lab exam for the Cisco Certified Internetwork Expert, for instance, costs about $\$ 1,250$ (Tittel 2006).
} 
distinguish three (ideal) types of certifiers: formal post-secondary education providers, vendor-specific certifiers, and vendor independents. ${ }^{11}$ Each type is positioned differently on a continuum from profit to not-for-profit orientation, with a strong vendor relatedness on one side and a strong state relatedness on the other side. Hence, they stand for a different degree of independence from the market and the government, respectively.

The first group is part of the formal post-secondary education system. Providers may be public entities or non-governmental bodies with delegated authority, often institutions of higher education. Vocational training programs for recognized occupations, which are provided by companies in cooperation with vocational schools, can also be included in this group. This first type is closely related to state regulation with frequent involvement of civil society, either on behalf of the academic community or within the framework of corporatism.

Both the second and the third group are more or less industry-based. The second group includes vendor-specific certifiers, whose programs are directly linked to a particular product - and thus to a distinct company (Adelman 2000:8; CEDEFOP 2006:8). Cisco, for example, offers programs for network tasks with three levels of certification. Other vendors offering similar services related to a particular product, platform, tool, or console include Microsoft, IBM, SAP, Novell, Oracle, and Red Hat, to name but a few (for a good overview on venderspecific certifiers, see CEDEFOP 2006:102-111; O'Sullivan et al. 2011). In such cases, standards tend to be extremely specific and related to one single software package. The move of software companies into the training market is part of their overall strategy to expand the service component in their business. They not only sell software and proprietary knowledge but also provide the verification of the appropriate competence to use this knowledge. Many of them do not provide the training themselves (O'Sullivan et al. 2011:17). They have outsourced this business to recognized partners while keeping the certification as their core business in this field. In other words, they keep the final word on the qualification standards underpinned by their software with a view to ensuring their supremacy in the training and certification market. Vendor-specific certification is the prevailing model in the United States and to a lesser extent in the European Union (EU), the second largest market for ICT certifications (Adelman 2000; Whitney 2007). ${ }^{12}$ The sheer number of certifications and programs offered by these companies fosters a search for market-based economies of scale, reinforcing a harmonization of profiles and standards.

The third group of certifiers is engaged in vendor-independent and more generic certification programs. The so-called vendor-neutral providers focus on issues, techniques, skills, and knowledge independent of a specific ICT product. Such certifiers are often organizations whose members include professional associations, IT companies, testing firms, consortia, and trade associations. One well-known vendor-neutral certifier is the Computing Technology Industry Association (CompTIA), with headquarters in Chicago, which offers certifications to individuals as well as to companies and instructors. ${ }^{13}$ It claims members in 102 countries, including manufacturers, distributors, retailers, solution, application or Internet service providers, software developers, and e-commerce and telecom companies. A more European-oriented consortium is Career Space, which includes 11 major ICT companies and the European Information and Communication Technology Industry Association (EICTA), representing 39 national digital technology consumer associations from 27 European countries. Career Space aims at developing a frame-

\footnotetext{
${ }^{11}$ This is a simplified typology derived from Povalej and Weiß (2007).

${ }^{12} \mathrm{~A}$ major exception in the United States was the now defunct National Skill Standards Board.

${ }^{13}$ Companies certified include BT, Cisco System, IBM Europe, Intel, Microsoft Europe, Nokia, Nortel Networks, Philips Semiconductors, Siemens AG, Telefonica. See http://certification.comptia.org (accessed March 2 2012).
} 
work for generic skills and competences required by the ICT industry in Europe. ${ }^{14}$ The profiles established so far are relevant for telecommunications, software development, services, and ICT management and sales.

Although this third type of certifier may be independent of a particular ICT product, they are not independent of the overall interests of the IT industry. These providers often represent the IT industry's interests in legislative procedure, before the courts or in the media. Some deliberately reach out to include interests from government, research, and academia. Vendor-independent certifiers with wider memberships, however, primarily aim at integrating prospective clients with considerable purchasing power, such as a particular industry or public administrations. Unsurprisingly, trade unions have rarely been included in the definition of job profiles and the related standards which inform training and certification programs, and most groups in civil society are even less closely involved. $^{15}$

This hybrid type of certifier is more inclusive than the vendor-specific certifiers and depends on public funding. The consortium Career Space, for instance, received financial support from the EU when it drew up some ICT curriculum development guidelines for universities (Career Space 2001). Public funding also plays a major role in the European effort to establish a European e-competence framework. A major driving force of this initiative, which is part of the e-skills strategy of the EU, is the Information Society Standardization System (ISSS) of the European Committee for Standardization (CEN) (see ISO 2007; CEN 2008). ${ }^{16}$ It is now known as the CEN-CENELEC ICT Forum, since the European Committee for Electrotechnical Standardization has joined the initiative, so as to respond to the challenge of converging technologies and increasing interests for further collaboration with industrial consortia. The project builds on existing standards, such as those of the Career Space consortium or of Council of European Professional Informatics Societies (CEPIS), and seeks to broaden its stakeholder base.

Public funding also plays a role in international standardization processes. Notably, the International Organization for Standardization (ISO) has emerged as an important player, establishing a wide range of standards for e-learning, which are also relevant for ICT training. Most ISO standards have so far focused on narrow technical specifications. ${ }^{17}$ Some, however, address broader issues such as the requirements for the management of training (ISO 10015:1999) and the certification of persons (ISO 17024:2003) (see also: IAF 2004). The most recent ISO standard established in the sphere of e-learning addresses the relationship between different concepts, such as competency, knowledge, skills, and qualifications (ISO/IEC TR 24763:2011). ${ }^{18}$

\footnotetext{
${ }^{14}$ See www.cepis.org (accessed March 2, 2012).

${ }^{15} \mathrm{~A}$ major exception is KIBNET, a German joint project funded by the Federal Ministry for Education and Research (BMBF) and involving the trade union IG Metall and the German Association for Information Technology, Telecommunications and New Media (BITKOM). The network emerging from this initiative was to be integrated into the European e-competence framework to which we will turn later on. For more information, see www. kibnet.org/english/index.html (accessed March 2, 2012).

${ }^{16}$ The European Commission adopted a long-term e-skill agenda in 2007 that includes foresight scenarios on supply and demand and suggestions on how to avoid e-skills shortages, gaps, and mismatch (European Commission 2007).

${ }^{17}$ ISO/IEC 24751-2:2008 focuses, for instance, on the individualized adaptability and accessibility in e-learning, education, and training. ISO/IEC 19778-1:2008 establishes norms for collaborative technology in this sphere.

${ }^{18}$ Other standards are ISO/IEC 23988:2007, which provides recommendations on the use of IT to deliver assessments to candidates and to record and score their responses, and ISO/IEC 19796-1:2005, which establishes a description scheme for quality management and describes a process model defining the basic processes to be considered when managing quality in the field of ICT training. As such, it provides generic quality standards for certifications, which have to be taken into account by the certifiers if they want to become ISO certified (Pawlowski 2007).
} 
This overview illustrates well the mixture of different private providers involved in the standard-setting process along a continuum from profit to not-for-profit orientation. Notably, vendor-specific certifiers have developed a strong market position with regard to specialized training programs that are related to specific features of their software. By contrast, not-for-profit providers offer training that is less product-dependent and more generic in nature. Many of them receive public funding or even involve public entities.

\section{Where and Whence Does Certification Become Authoritative?}

The non-state authority of various certifiers is exercised on multiple scales within differentiated spatial scopes, playing out the opposing endogenous and exogenous principles of recognition. The certifications of the formal post-secondary education providers focus on ICT skills in a more general educational framework. Their authority is closely related to a societal consensus organized by government, together with the national parliament and the teaching profession. As higher education institutions, these providers are part of an endogenous public recognition regime. However, the ability of these institutions to respond adequately and rapidly in light of the new skill requirements introduced by the knowledge-based economy has been challenged in recent years (Wood and Revill 2004; OECD 2006:11). In response, many higher education institutions have begun to outsource part of their IT training to industry-based trainers and certifiers whose authority is closely related to their software and to the general assumption that they know how to make best use of it (Adelman 2000). This leads to a new form of commodification in public education, with industry-based certifiers benefiting from the public funding of the universities to which they offer their services (Schiller 2000:143-202; Hartmann, Haslinger and Scherrer 2006).

The blurring of public and industry-based certifiers has gone even further. A number of higher education institutions have agreed to waive some of their general entrance requirements for holders of ICT certifications. ${ }^{19}$ Associations such as the American Council on Education have started to support this trend by providing guidance regarding the recognition of nontraditional degree programs. ${ }^{20}$ This includes 21 products in the portfolio of Microsoftcertified IT skills (American Council on Education 2011). Such cases illustrate how the distinction between formal and nonformal types of education is blurring in the emerging knowledge-based economy where a timely, reliable, and constant renewal of skills has become instrumental and has been delegated to the market to a great extent. While post-secondary education providers still have formal authority based on an endogenous logic of recognition within the public domain, they often lack the expertise and resources provided on a more exogenous basis by what Adelman designated the "parallel universe" of industry-based certifiers. This challenge to the state as the competent provider of qualifications is part of a more general transformation of public services, whereby the state is more and more reduced to the role of the financier while the delivery of public services is delegated to private, often profit-oriented providers (Newman and Clarke 2009). The outsourcing may take place for the sake of reducing costs, but also, as in our case, of inadequate state capabilities.

\footnotetext{
${ }^{19}$ For instance, the Western Governors University, founded by the governors of the Western states to expand access to higher education for working adults through online programs, waives up to $25 \%$ of its degree requirements. See www.wgu.edu/cml4 (accessed March 2, 2012).

${ }^{20}$ See www.acenet.edu/Content/NavigationMenu/ProgramsServices/CCRS/index.htm (accessed March 2, 2012).
} 
The reputation of the two different types of industry-based training and certification is underpinned by the different dynamics impinging on the spatial scope of their authority. Initially, vendor-independent certifications, developed by professional associations as a form of self-regulation, played the leading role in ensuring standards and competences in the computing profession. However, as studies show, none of these certifications gained broad recognition by the industry (CompTIA 2004:19). The birth of networked computing and the growth of the ICT industry in the late 1980s tilted the certification landscape in favor of the vendor certifiers (Whitney 2007). The authority of this second type of certifier is closely related to the market force of their software and technology. The knowledge of their own new software and technology allows them to provide the required training and certifications in a timely manner. This clear comparative advantage in the training and certification market explains why vendor-specific certifiers pulled ahead of vendor-independent certifiers in the 1980 s and dominate the market today. The authority of these providers is strongly related to their market share. Many of the vendors are located in the United States, where they benefit from a large domestic market (Tittel 2006). The bigger the market share, the more likely employers are to know the certification, which in turn increases the value of the certification. Once widely known, certifications attract even more clients including companies and public administrations that outsource the ICT training of their staff (Tyler 2004).

Industry-based certifications also have the edge over post-secondary education institutions with regard to the international recognition of their degrees. International mechanisms enabling the international recognition of formal qualifications exist only to a very limited extent (Hartmann 2010). Many governments are still reluctant to recognize degrees and certifications issued in other countries, even though such recognition is vital for the mobility of skilled labor (Mattoo and Mishra 2009). In this context, international certification procedures established by private bodies are gaining momentum. As private providers they can easily offer their training programs and certifications in different countries as part of the emerging global service economy. In addition, they derive benefits from the fact that their authority essentially rests on the exogenous logic of their reputation without requiring an endogenous basis of a regulatory authority in a legal sense. In other words, they merely depend on the recognition of employers in the host country. The ability to enhance the transnational credibility of certifications is therefore crucial for this type of provider. The fact that even some immigration authorities have started to take certifications into account when assigning work permits is insightful in this regard (Whitney 2007). Vendorspecific certifiers benefit from the internationalization of the software market, which further underpins their international reach, fostering a winner-takes-all dynamic. Furthermore, in light of global migration, widely known certifications build on the attractiveness of the labor market of their home country. IT professionals from low-income countries are more likely to pursue the certifications that facilitate their access to high-income labor markets. Certifiers also benefit from the international activities of other service providers of their country of origin, as multinational companies setting up new affiliates abroad may prefer employees with certifications they already know from their home country. Many of them also use international certifications to harmonize their human resources development (Bartlett, Horwitz, Ipe and Liu 2005). Internationally known certifications also play an important role in the outsourcing of skilled tasks offshore in such places as India, Vietnam, or the Philippines (Tyler 2004). They may be seen as trustworthy indicators of the subcontracting companies' quality, notably when these companies are situated in countries with a formal education system substantially different from the one of the outsourcing companies' country of origin. 
This role of the market spotlights an important shift in the practice of recognition of qualifications at international level, one that blurs both the distinction between exogenous and endogenous principles of recognition and that between public and private. However, there is evidence that profit-oriented certifiers, in particular, face intrinsic limits to the exercise of their authority. Vendor certifications have indeed attracted major criticism in recent years for being too biased toward their own solutions and technology and are seen as only being interested in building a pool of trusted technicians who know how to implement and support their product, if possible at a worldwide level. The criticism, put forward by consumers and IT professional associations, highlights the boundaries of the market-driven logic at play (Wyrostek 2008). Critics fear that profit motives lead to an expansion of the certification market that is likely to be to the detriment of a sound quality control, including a range of different stakeholders (French 2010). In contrast, vendor-independent certifiers, being less-market driven, build their authority on well-established mechanisms for consulting members, including a wide range of associations and industry groups, before establishing specific programs and control mechanisms. Some of these members may gain their authority from an exclusive and close relationship with industry, while others build on government, research, and academic connections. Nevertheless, they face a dilemma which puts them at a disadvantage as compared to vendor certifiers. Their effort to differentiate their offer from others in a proliferating market has resulted in a highly fragmented and confusing landscape of vendor-independent certifications, often lacking transparency and comparability (CEDEFOP 2006). The growing confusion makes it difficult for prospective trainees and employers to distinguish between good offers and mediocre or frankly bad ones. This has considerably undermined the reputation of a number of vendor-independent certifiers (Tittel 2006). Furthermore, vendor-independent certifiers cannot benefit to the same extent as vendor-certifiers from economies of scale on the international plane of the global market of ICT products and services. However, in the future, consolidation may provide a favorable option for vendor-independent certifiers.

\section{Toward the Consolidation of ICT Certification}

Our analysis has shown that ICT training and certification programs reach out beyond narrow technical skills to include a wide range of societal issues and involving private companies and organizations close to the IT industry. They exercise a form of authority that can be recognized independently from the territorial basis of state sovereignty. However, recent developments in ICT training and certification make clear that such a privatized and transnational form of nonstate authority faces some limits. A first lesson to be drawn is that the more technical specifications take social behavior into account, the more profit-oriented nonstate standard setters face limits in exercising their transnational authority. Yet nonprofit private actors, such as vendor-neutral certifiers, can hardly benefit from this situation due to their limited scope and internal fragmentation.

In this context, the EU plays a vital role, not through establishing its own standards but by supporting vendor-neutral standards. A well-known example is the European Computer Driving Licence (ECDL), known outside Europe as the International Computer Driving Licence (ICDL), established in 1995 with the support of some EU funding (Stucky et al. 2003; Calzarossa et al. 2007:516). By 2012, it had certified about 11 million people, in 41 languages, across 148 countries, through a network of over 24,000 test centers. ${ }^{21}$ The standards of this license have been elaborated by the professional association CEPIS, which

${ }^{21}$ These figures are provided by the CDL Foundation's Web site. See www.ecdl.org (accessed March 2, 2012). 
represents 37 member societies in 33 European countries. ${ }^{22}$ In 2002, CEPIS launched the European Certification of Informatics Professionals (EUCIP), which complements the more end-user-oriented ECDL and provides a pan-European qualification scheme for people entering the ICT profession, as well as for advanced ICT training (PR Newswire Europe 2002).

Official standard-setting organizations closely linked to the EU also aim at developing more generic standards with wider reach. One driving force has been the ISSS of the European Committee for Standardization (CEN) (known now as CEN-CENELEC ICT Forum), in close collaboration with a number of professional associations, universities, and European institutions, as well as private companies such as Airbus, Deutsche Telekom, Cisco Systems, and Microsoft (ISO 2007; CEN 2008). This loosely institutionalized collaboration initiated various workshops on ICT skills with representatives from industry, vocational training organizations, social partners, and other institutions resulting in a number of CEN Workshop Agreements (CWA). ${ }^{23}$ For instance, CWA 16052:2009 sets out guidelines for certifiers, vendor-specific and neutral providers alike, including standards for information and quality assurance requirements, based on selfassessment with peer review. The most important agreement with regard to a more generic consolidation is CWA 15893, updated in 2010 as CWA 16234 (CEPIS 2011). This document sets up a European e-Competence Framework (e-CF) in relation to the European Qualifications Framework (EQF) established for lifelong learning (European Commission 2007; European Parliament and Council 2008; Weiss, O'Sullivan and Sharkov 2011).

The European Model for certification schemes is, however, not restricted to European standards. It is also consistent with ISO standards. ${ }^{24}$ In this sense, the CEN/ISO standards are instrumental in challenging the predominance of vendor certifications at the global level. In many respects, standards for ICT certifiers have even become a model for regulating nonformal education in general. A case in point is the development of ISO 29990:2010 which established standards for providers of nonformal education as a whole (see also ISO 2009:31-34).

This short overview of the current international consolidation highlights the continuing importance of public funding and intergovernmental cooperation for establishing more generic, product-independent standards. Their organizational and financial role helps to counter the oligopolistic standard-setting practices of those who advocate a commodification of narrowly defined technical ICT certifications based entirely on industry products. It has also illustrated that the more generic the norms are, the more likely they are to become a model for nonformal education as a whole, which has become paramount in a world with a short life cycle of knowledge where lifelong learning has become the norm.

\section{Conclusion}

This article has analyzed how the ICT infrastructure for the tradability of services in a global knowledge-based economy relies on the continuous adjustment of ICT expertise, standardized by nonformal education provided by companies and associations. Such nonformal education in ICT training and certification is part

\footnotetext{
${ }^{22}$ For more information, see www.cepis.org. Italy for instance has introduced EDCL at most of its universities (Calzarossa et al. 2007:516).

${ }^{23}$ See also www.cen.eu/cen/Sectors/Sectors/ISSS/CEN\%20Workshop\%20Agreements/Pages/ICT-Skills.aspx (accessed March 2, 2012).

${ }^{24}$ The relevant ISO standards are ISO/IEC 24773:2008 (Certification of Software Engineering Professionals), ISO/IEC TR 19759:2005 (Software Engineering) and EN ISO/IEC 17024:2003 (General requirements for bodies operating certification of persons).
} 
of an emerging market with its own standard-setting authority. Our conceptual framework brings together three closely related dimensions of hybrid authority for international standards in the service economy. It situates the role of technical specifications in the current power configurations of the emergent knowledge-based economy within the broader perspective of the issues concerned, the range of nonstate actors involved, and the scale and spatial scope of their authority. Our case study has highlighted that ICT training and certification programs tend to include a broader range of societal values than is usually recognized. Whereas programs rely to a great extent on state-of-the-art computer and software developments, the analysis shows that the definition and certification of ICT skills and reliability also affect working conditions and future wage expectations. Regarding the nonstate actors involved, the analysis substantiates the assumption that two types of private standard setters are currently superseding traditional formal education systems in the sphere of lifelong learning: vendor certifiers and vendor-independent certifiers. Finally, assessing the scale and spatial scope of such new forms of nonstate authority, our study maps the extent to which such ICT training and certification programs are recognized independently from the territorial basis of state sovereignty. Our conceptual framework highlights that the significance of such transnational authority rests upon its ability to assimilate, in one process, technical measures and societal values, to blur distinctions between private and public actors and to rearrange to a considerable extent the spatial configuration of regulatory practices in contemporary capitalism. The role of the ISO and the EU in the consolidation of transnational authority of nonprofit actors should thus be seen in this context, as an attempt to engage with the private firms predominantly setting the standards. The role of standards and certification in the continuous adjustment of ICT expertise in a global knowledge-based economy thus remains contestable with regard to the issues concerned, the actors involved, and the scale and scope of their authority.

On a theoretical basis, one implication is that the market has become a crucial mechanism in its unique ability to provide rapid adjustments geared to the skills required in a knowledge-based economy. Our study has shown that the more societal and generic standards are, the more their creation depends on public policy support. However, even though such instruments are more inclusive than those sold by private firms, they remain highly selective, predominately targeting groups with considerable market power and excluding trade unions and other less powerful actors in civil society. This raises the question of how public should public policy be in the age of globalization. Further research is needed to fully grasp this shift in state/market relations in providing market enabling infrastructure. Another implication is that privatized forms of regulatory instruments support their internationalization. Taking into account the societal values such instruments embody, this has major consequences for the socialization processes underpinning state power. In light of the role of education in the construction of nation-states, our findings show the field of ICT training to be a case in point; it could easily be complemented by studying the transnationalization of socialization processes in other core domains and its consequences for state power.

In conclusion, the particular tension between profit orientation and reputation underlying - and limiting - transnational authority in a knowledge-based economy will certainly persist. This, in turn, will generate contestation about the nature and level of trust required for market transactions-and the status of knowledge in the organization of contemporary society. As emphasized by Callon, Méadel and Rabeharisoa (2002:196), a service economy is likely to lead to a "profound transformation of the rules by which markets function... The organization of markets becomes a collective issue and the economy becomes (again) political." This brings us back to the contestability of the institutional framework ensuring some sort of order at the transnational level. Future 
research should thus explore in which direction the pendulum is swinging, the degree to which this varies according to different classes of objects, and what the actors involved make of it.

\section{References}

Adelman, Clifford. (2000) A Parallel Postsecondary Universe: The Certification System in Information Technology. Washington, DC: Office of Educational Research and Improvement, U.S. Department of Education.

American Council on Education. (2011) National Guide to College Credits for Workforce Training. Washington, DC: College Credit Recommendation Service.

Amin, Ash. (2004) Regulating Economic Globalization. Transactions of the Institute of British Geographers 29: 217-233.

Anzelmo, Erin L. (2006) Cyberspace in International Law: Does the Internet Negate the Relevance of Territoriality in International Law? Studia Diplomatica 58: 153-169.

Australian Governement. (2011) Whole-of-Government ICT Strategic Workforce Plan 2010-2013.

Avant, Deborah D., Martha Finnemore, and Susan K. Sell, Eds. (2010) Who Governs the Globe? Cambridge: Cambridge University Press.

Bartlett, Kenneth R., Sujin K. Horwitz, Minu Ipe, and Yuwen Liu. (2005) The Perceived Influence on Industry-Sponsored Credentials on the Recruitment Process in the Information Technology Industry: Employer and Employee Perspective. Journal of Career and Technical Education 21.

Bell, Daniel. (1973) Coming of Post-Industrial Society: A Venture in Social Forecasting. New York: Basic Books.

Brand, Ulrich. (2005) Order and Regulation: Global Governance as a Hegemeonic Discourse of International Politics. Review of International Political Economy 12: 155-176.

Brenner, NeIL. (2004) New State Spaces. Oxford: Oxford University Press.

Brenner, NeIL. (2009) Open Questions on State Rescaling. Cambridge Journal of Regions, Economy and Socitety 2: 123-139.

Callon, Michel. (1998) Introduction: The Embeddedness of Economic Markets in Economics. In The Laws of the Markets, edited by Michel Callon. Oxford: Blackwell.

Callon, Michel, Cécile Méadel, and Vololona Rabeharisoa. (2002) The Economy of Qualities. Economy and Society 31: 194-217.

Calzarossa, Maria Carla, Paolo Ciancarini, Paolo Maresca, luisa Mich, and Nello Scarabottolo. (2007) The ECFL Programme in Italian Universities. Computers E Education 49: 514-529.

Cameron, Angus, and Ronen Palan. (2003) The Imagined Economies of Globalisation. London: Sage.

Career Space. (2001) Curriculum Development Guidelines: New ICT Curricula for the 21st Century.

Castells, Manuel. (2001) La Société en Réseaux, 2nd ed. Paris: Fayard.

CEDEFOP. (2006) ICT Skills Certification in Europe. Thessaloniki: European Centre of the Development of Vocational Training (Cedefop).

CEDEFOP. (2008) Terminology of European Education and Training Policy. A Selection of 100 Key Terms. Luxembourg: Office for Official Publications of the European Communities.

CEDEFOP. (2009) ICT and E-Business Skills and Training in Europe. Towards a Comprehensive European ESkills Reference Framework: Final Synthesis Report. Tessaloniki: European Centre for the Development of Vocational Training.

CEN. (2008) A Common European Framework for ICT Professionals in All Industry Sectors European ECompetence Framework 1.0. Brussels: European Committee for Standardization, European Commission.

CEN. (2009) E-Certification Market. Final Report, Issue 2.0, Cen Workshop ICT—Skills. European Committee for Standardization.

CEPIS. (2007) Thinking Ahead on E-Skills for the ICT Industry in Europe. Council of European Professional Informatics Societies.

CEPIS. (2011) Cepis Survey of Professional E-Competence in Europe. European Report. Council of European Professional Informatics Societies.

Cerny, Philip. (2009) Bridging the Transatlantic Divide? Towards a Structural Approach to International Political Economy. In Routledge Handbook of International Political Economy (IPE), edited by Marc Blyth. London: Routledge.

Colàs, Alejandro. (2002) International Civil Society. Cambridge: Polity. 
Comor, Edward A. (1999) Governance and the Nation-State in a Knowledge-Based Poitical Economy. In Approaches to Global Governance Theory, edited by Martin Hewson, and Timothy Sinclair. Albany: SUNY Press.

CompTIA. (2004) The Situation and the Role of E-Skills Industry Certification in Europe. The e-skills Certification Consortium (eSCC).

CompTIA. (2012) IT Executives Optimistic About the Future. Certification Magazine, January.

Coоmbs, Philıp H. (1968) World Educational Crisis: A Systems Approach. New York: Oxford University Press.

Coombs, Philip H., And Manzoor Ahmed. (1974) Attacking Rural Poverty: How Non-formal Education Can Help. Baltimore: Johns Hopkins University Press.

Cutler, A. Claire. (2003) Private Power and Global Authority. Cambridge: Cambridge University Press.

Cutler, A Claire, Virginia Haufler, and Tony Porter, Eds. (1999) Private Authority and International Affairs. New York: SUNY Press.

Djelic, Marie-Laure, and Kerstin Sahlin-Andersson, Eds. (2006) Transnational Governance. Cambridge: Cambridge University Press.

Drissel, David. (2006) Internet Governance in a Multipolar World: Challenging American Hegemony. Cambridge Review of International Affairs 19: 105-20.

Duffield, Mark. (2007) Development, Security and Unending War. Cambridge: Polity.

Egan, Michelle. (2001) Constructing a European Market. Oxford: Oxford University Press.

Ericson, Richard, Aaron Doyle, AND DeAn BARry. (2003) Insurance as Governance. Toronto: University of Toronto press.

European Commission. (2007) E-Skills for the 21st Century: Fostering Competitiveness, Growth and Jobs, Communication to the Council, the European Parliament, the European Economic and Social Committee and the Committe of the Regions, Com(2007) 496 Final, September 7. Brussels: European Union.

European Parliament, and Council. (2008) Recommendation of the European Parliament and the Council on the Establishment of the European Qualifications Framework for Lifelong Learning, January 29 2008, Pe-Cons 3662/07. Brussels: European Union.

Feenberg, Andrew. (1991) Critical Theory of Technology. New York: Oxford University Press.

Foote Partners LLC. (2011) IT Skills Demand and Pay Trends Report-1st Quarter.

Fox, Janna D., Mari Wesche, Doreen Bayliss, Liying Cheng, Carolyn E. Turner, and Christine Doe. (2007) Language Testing Reconsidered. Ottowa: University of Ottowa.

French, Matthew. (2010) Why IT Certification Matters. TechCentral.

Gill, Stephen, Ed. (1993) Gramsci, Historical Materialism and International Relations. Cambridge: Cambridge University Press.

Grande, Edgar, and Louis W. Pauly, Eds. (2005) Complex Sovereignty. Toronto: University of Toronto Press.

Graz, Jean-Christophe, and Nafi Niang. (2012 forthcoming) Connecting India: The Rise of Standards in Service Offshoring. The Service Industries Journal 32: 12.

Graz, Jean-Christophe, and Andreas Nölke, Eds. (2008) Transnational Private Governance and Its Limits. London: Routledge.

Hall, Rodney Bruce, and Thomas J. Biersteker, Eds. (2002) The Emergence of Private Authority in Global Governance. Cambridge: Cambridge University Press.

Hallström, Kristina TAmm. (2004) Organizing International Standardization: ISO and the IASC in Quest of Authority. Cheltenham, UK; Northampton, MA: Edward Elgar.

Hartmann, Eva. (2008) The Role of Qualifications in the Global Migration Regime. GARNET Working paper, No: 39/08.

Hartmann, Eva. (2010) The United Nations Educational, Scientific and Cultural Organisation: Pawn or Global Player? Globalisation, Societies and Education 8: 307-318.

Hartmann, Eva, Sebastian Haslinger, and Christoph Scherrer. (2006) Liberalization of Higher Education and Training: Implications for Workers' Security. In Winners or Losers: Liberalizing Public Services, edited by Ellen Rosskam. Geneva: International Labour Organisation.

Hauert, Christophe, and Jean-Christophe Graz. (2010) Services Standardization in the UnitedStates and in Europe: An Institutional Analysis of Private Authority. In 15th Euras Annual Standardisation Conference 'Services Standardisation', edited by Jean-Christophe Graz, Kai Jacobs. Verlaghaus Mainz.

Haufler, Virginia. (1997) Dangerous Commerce. Ithaca, NY: Cornell University Press.

Héritier, Adrienne, Ed. (2002) Common Goods. Lanham, MD: Rowman \& Littlefield.

Hewson, Martin, and Timothy J. Sinclair, Eds. (1999) Approaches to Global Governance Theory. Albany: State University of New York Press. 
Higgins, Vaughan, and Wendy Larner, Eds. (2010) Calculating the Social. London: Palgrave Macmillan.

Higgott, Richard, Geoffrey Underhill, and Andreas Bieler, Eds. (1999) Non-state Actors and Authority in the Global System. London and New York: Routledge.

Holman, Oтto. (2008) Public-Private Partnerships and Transnational Governance in the European Union: The Case of the Lisbon Strategy. In Transnational Private Govenance and Its Limits, edited by Jean-Christophe Graz, and Andreas Nölke. London: Routledge.

IAF. (2004) IAF Guidance on the Application of ISO/IEC 17024:2003 Conformity Assessment-General Requirements for Bodies Operating Certification of Person. Cherrybrook: International Accreditation Forum.

IDC. (2008) Worldwide and U.S. Corporate Elearning 2008-2012 Forecast. Farmingham, MA: International Data Corporation.

ISO. (2007) Education for All. ISO Focus, November.

ISO. (2009) Continual Competence. ISO Focus, November/December: 31-34.

Jessop, Вов. (2002) The Future of the Capitalist State. London: Polity.

Krause Hansen, Hans, and Dorte Salskov-Iversen, Eds. (2008) Critical Perspectives on Private Authority in Global Politics. Houndmills: Palgrave Macmillan.

Levy, David L., and Peter Newell, Eds. (2005) The Business of Global Environmental Governance. Cambridge, MA: MIT Press.

Lisican, Elizabeth. (2008) The Future of IT: Hybrid Jobs. Certification Magazine, November. Available at www.certmag.com/read.php?in=3643 (accessed June 25, 2012).

Loconto, Allison, and Lawrence Busch. (2010) Standards, Techno-Economic Networks, and Playing Fields: Performing the Global Market Economy. Review of International Political Economy 17: 507-536.

Margolis, Daniel. (2007) ComptiA Developing Printing and Documenting Imaging Certifications. Certification Magazine, April. Available at www.certmag.com/read.php?in=2725 (accessed June 25, 2012).

Mathiason, John. (2009) Internet Governance. London: Routledge.

Mattli, Walter, And Tim Buthe. (2011) The New Global Rulers. Princeton, NJ: Princeton University Press.

Mattli, Walter, and Ngaire Woods, Eds. (2009) The Politics of Global Regulation. Princeton, NJ: Princeton University Press.

Mattoo, Aaditya, and Deepak Mishra. (2009) Foreign Professionals in the United States: Regulatory Impediments to Trade. Journal of International Economic Law 12: 435-456.

Miles, IAn, AND Marcela Miozzo, Eds. (2002) Internationalization, Technology and Services. Cheltenham: Edward Elgar.

Mügge, Daniel. (2010) Widen the Market, Narrow the Competition. Colchester: ECPR Press.

Newman, Janet, and John Clarke. (2009) Publics, Politics and Power: Remaking the Public in Public Services. London: Sage.

Nicolaïdis, Kalypso, and Michelle Egan. (2001) Transnational Market Governance and Regional Policy Externalities: Why Recognize Foreign Standards? Journal of European Public Policy 8: 454 473.

OECD. (2006) Information Technology Outlook 2006. Highlights. Paris: Organisation for Economic Co-operation and Development.

OECD. (2010) OECD Science, Technology and Industry Outlook 2010. Paris: Organisation for Economic Cooperation and Development.

O'Sullivan, John, Peter Weiss, and George Sharkov. (2011) ICT Certification in Action, 3 May 2011, Draft Final Report. European Committee for Standardization.

Ougaard, Morten, And AnNa Leander, Eds. (2010) Business and Global Governance. London: Routledge.

Palan, Ronen. (2003) The Offshore World. Ithaca, NY: Cornell University Press.

Pawlowski, Jan M. (2007) The Quality Adaptation Model: Adaptation and Adoption of the Quality Standard ISO/IEC 19796-1 for Learning, Education, and Training. Educational Technology and Society 10: 3-16.

Povalej, Roman, and Peter Weiss. (2007) Survey of ICT Certification Systems for ICT Professionals in Europe. Upgrade- the European Journal for the Informatics Professional 8: 36-45.

Prakash, Aseem, and Matthew Potoski. (2006) The Voluntary Environmentalists. Cambridge: Cambridge University Press. 
Risse, Thomas. (2006) Transnational Governance and Legitimacy. In Governance and Democracy. Comparing National European and International Experiences, edited by Arthur Benz, and Yannis Papadopoulos. London: Routledge.

Robert Half Technology. (2011) 2012 Salary Guide.

Sassen, Saskia. (2006) Territory, Authority, Rights. Princeton, NJ: Princeton University Press.

Schiller, Dan. (2000) Digital Capitalism-Networking the Global Market System. Cambridge: The MIT Press.

Smismans, Stijn. (2004) Law, Legitimacy, and European Governance. Oxford; New York: Oxford University Press.

Strange, Susan. (1996) The Retreat of the State. Cambridge: Cambridge University Press.

Stucky, Wolffried, Matthew Dixon, Peter Bumann, and Andreas Oberweis. (2003) Information Technology Practitioner Skills in Europe: Current Status and Challenges for the Future. In Computer Science in Perspective, edited by Rolf Klein, Hans-Werner Six, and Lutz Wegner. Berlin: Springer.

Summerfield, Brian. (2007) Funding Your Certification. Certification Magazine, August. Available at www.certmag.com/read.php?in=3002 (accessed June 25, 2012).

Sussman, Joseph M. (2005) Perspectives on Intelligent Transportation Systems (ITS). New York: Springer.

Tegan, Jones, Daniel Margolis, Brian Summerfield, Kellye Whitney, and Sarah Stone Wunder. (2006) Certmag's 2006 Salary Survey. Certification Magazine, October. Available at www. certmag.com/read.php?start=24348\&in=3656 (accessed June 25, 2012).

TitTel Ed. (2003) Studying for Vendor-Neutral Versus Vendor-Specific Exams. Certification Magazine, October. Available at www.certmag.com/read.php?in=429 (accessed June 25, 2012).

Tittel, Ed. (2006) Certification Top 10 Lists Revisited. Certification Magazine, November. Available at www.certmag.com/email.php?in=2401 (accessed June 25, 2012).

Tong, Alex. (2008) The China Boom. In Certification Magazine, August.

Tyler, Kathryn. (2004) Carve out Training? HR Magazine 49. Available at www.certmag.com/read. php?in=3545 (accessed June 25, 2012).

UNDP. (2007) Ict Skill Development in the Asia-Pacific Region, Part One: The Gap between Demand and Supply, APDIP E-Note 13. Bangkok: United Nations Development Program.

Weiss, Charles. (2005) Science, Technology and International Relations. Technology in Society 27: 295-313.

Weiss, Peter, John O’Sullivan, and George Sharkov. (2011) ICT Certification in Action: Positioning Methodology of E-Certs against E-Cf. In Echallenges E-2011 Conference Proceedings, edited by Paul Cunningham, and Miriam Cunningham. IIMC International Information Management Corporation.

Whitney, Kellye. (2007) The International Market for Certification. Certification Magazine, May: 20-21.

Wilson, Ernest J. (2005) What Is Internet Governance and Where Does It Come From? Journal of Public Policy 25: 29-50.

Wood, Stirling, and Peter Revill. (2004) The Inclusion of Vendor Certifications in National Qualifications. Paper presented at the Workshop on e-skills industry certifications, Brussels.

World BANk. (2011) World Bank: Sector Strategy Information E Communication Technologies Approach Paper, March 24-25. Washington, DC: World Bank.

Wyrostek, Warren E. (2008) The Top 10 Problems with IT Certification in 2008. InformIT, March 14. Available at www.ciscopress.com/articles/article.asp?p=1180991 (accessed June 25, 2012).

ZuUrmond, Arre. (2005) Organisational Transformation through the Internet. Journal of Public Policy 25: $133-148$. 